\title{
Surveillance \& Society Police Use of Body-Worn Cameras: Article Challenges of Visibility, Procedural Justice, and Legitimacy
}

\section{Ermus St. Louis}

University of Illinois, Chicago, USA

esaint2@uic.edu

\section{Kevin Walby}

University of Winnipeg, Canada

k.walby@uwinnipeg.ca

\section{Alana Saulnier}

Lakehead University, Canada

alana.saulnier@lakeheadu.ca

\begin{abstract}
Recent controversies over police use of force in the United States of America have placed a spotlight on police in Western nations. Concerns that police conduct is racist and procedurally unjust have generated public sentiments that accountability must be externally imposed on police. One such accountability mechanism is body-worn cameras (BWCs). Optimistic accounts of BWCs suggest that the technology will contribute to the improvement of community-police relations. However, BWCs address consequences, not causes, of poor community-police relations. We argue that the evolving visibility of police associated with BWCs is double-edged, and suggest that the adoption of surveillance technologies such as BWCs in the quest to improve community-police relations will fail without a simultaneous commitment to inclusionary policing practices (such as community policing strategies, community and social development, and local democracy). We outline two initiatives that optimize BWCs by promoting these simultaneous commitments.
\end{abstract}

\section{Introduction}

On July 17, 2014, Eric Garner was approached by two New York Police Department (NYPD) officers on suspicion of selling untaxed cigarettes. A citizen's recording of the encounter showed a frustrated Garner exclaiming, "Every time you see me, you want to mess with me. I'm tired of it. This stops today. It's over!" About 10 minutes later, it was over. Garner died of asphyxiation after being placed in a chokehold - a tactic banned by the NYPD in 1993 (Snyder et al. 2017). A succession of high-profile police-involved deaths of unarmed African Americans followed in 2014, sparking public outrage and renewing the national debate about race and policing in the United States of America (USA). Twentythree days later, an officer shot and killed Michael Brown in Ferguson, Missouri. This case intensified public accusations of police brutality and calls for accountability. Public frustration was marked by nationwide protests. Adding to public angst was the police-involved shooting death of 12-year-old Tamir Rice in November as he played with a toy gun in a Cleveland, Ohio, park. Approximately a month before this tragic incident, Laquan McDonald was fatally shot for allegedly approaching Chicago Police Department (CPD) officers in a threatening manner with a knife. Video footage released by the CPD did 
not corroborate officers' accounts. The video revealed that the officer 'came out of his vehicle, gun raised and immediately fired off 16 shots. The first shot hit [McDonald], and he immediately fell to the ground. While he lay motionless, [the officer] continued to unload his clip, firing 16 shots [into McDonald's] body" (PATF 2016: 2). The grizzly images fuelled public discontent and bolstered opinions that police cannot be trusted to hold themselves accountable.

These controversial events contributed to a police legitimacy crisis in the USA (Wolfe and Nix 2016; Miller 2016), with body-worn cameras (BWCs) framed as a technological solution (USA White House 2014; Ariel, Farrar, and Sutherland 2015; Jameel and Bunn 2015). A BWC is a portable "device that allows officers to record what they see and hear" (Hayes and Ericson 2012: 5). The adoption of BWCs is an aspect of technologically-mediated policing that increases officer and citizen visibility. While optimistic accounts of BWCs have concentrated on the legitimacy-enhancing prospects of the technology, BWCs can also be characterized as a "tool of exposure" (Goldsmith 2010: 919), rendering police visible like never before. This new police visibility is not inherently legitimizing, but double-edged, also presenting challenges to community-police relations.

We focus on police developments in the USA, although we believe our claims are applicable to other settings in which BWCs are used. While policing in Canada (see O'Neil 2013) and many European nations may not be experiencing a legitimacy crisis like in the USA, the diffusion of BWCs and other police surveillance technologies worldwide has created a crisis of visibility for the profession that transcends national boundaries (Haggerty and Sandhu 2014; Sandhu and Haggerty 2017). The crisis of visibility is directly related to underlying community-police power imbalances, a factor that is also at the heart of the police legitimacy crisis given that police have historically "relied on their low [visibility] as an important power resource. Today, however, the police's visible field is shifting, at least in part due to how policing increasingly occurs on camera" (Haggerty and Sandhu 2014: 9-10). Alongside the increase in visibility is the gradual creation of a political environment to support major legal changes that notably extend police power, thus exacerbating the conditions that cause the public to question police legitimacy (Davis 2007). Furthermore, official reaction to both types of crises typically follows similar responses. They both stimulate responses characterized as "expressive gestures" (Norris and McCahill 2006) and "non-adaptive responses" (van Brakel and De Hert 2011), which operate to maintain an unacceptable level of power asymmetries between police and the public. The adoption of BWCs is an expressive gesture when conceptualized as a visible reaction to public concerns with police transparency and accountability. As a result, BWC policy-making tends to be reactive, or non-adaptive. Recommendations for optimizing police use of BWCs tend to be technologically focused, leaving unaddressed the relational concerns underlying the power imbalance that is, in part, prompting the uptake in BWCs.

As such, we reflect on police acquisition of BWCs with caution, arguing that BWCs will only contribute to the improvement of community-police relations alongside a broader commitment to inclusionary policing practices such as community policing, social development, and local democracy. Inclusionary practices involve an active, ongoing collaboration between citizens and officers. We maintain that without serious commitment to inclusionary practices, BWCs will only be a technological bandage, addressing consequences, not causes, of poor community-police relations. Highlighting BWCs as a flawed panacea to the challenges of contemporary policing is increasingly common (e.g., Feeney 2015; Gonzales and Cochran 2017). However, critical commentary on BWC-policing tends to focus on the technical aspects of BWC use, such as which recording policies should accompany BWC adoption (e.g., Taylor 2016; Thomas 2016), and the integration of privacy concerns into policies of evidence collection and data management (e.g., Piza 2018; Suss et al. 2018). Adding to this work, we propose two initiatives designed to optimize BWCs through inclusionary policing practices that are attentive to the relational concerns that comprise public perceptions of police legitimacy.

First, we highlight the current police legitimacy crisis in the USA and the related status of communitypolice relations, introduce procedural justice theory as a dominant explanation for how those relations are formed, and reflect on the importance of positive community-police relations to policing. Second, we 
summarize the genealogy of BWCs in relation to the current legitimacy crisis, review empirical data on public perceptions of BWCs, and highlight the prospects BWCs offer for resolving legitimacy concerns framed through the lens of procedural justice theory. The next section engages with police adoption of BWCs from a more critical perspective, reflecting on key challenges that BWCs may pose to improving community-police relations and offering descriptions of two initiatives we believe will be useful in addressing these legitimacy concerns alongside the adoption of BWCs.

\section{The Crisis of Police Legitimacy}

Positive community-police relations are essential to effective policing, and public perceptions of police legitimacy are key to these positive relations. In modern police history, the construction of police legitimacy has been central to the success of policing (Reiner 2010; Smith 2007) and, in turn, the ability of the state to function (Bradford et al. 2014). Public perceptions of police legitimacy are linked to advantageous outcomes for legal authorities, including adherence to the law (Jackson et al. 2012; Murphy 2014; Tyler 2006) and compliance with police (Jonathan-Zamir, Hasisi, and Margalioth 2016; Tyler and Huo 2002).

Policing in the USA is experiencing a legitimacy crisis, with the public demanding reform and accountability (Leila and Bunn 2015; Wolfe and Nix 2016; USA White House 2014). Legitimacy is the belief that authority should be obeyed (Sunshine and Tyler 2003); therefore, a police legitimacy crisis is characterized by waning public belief that police are entitled to be obeyed. The incidents described previously, in which unarmed persons died as a result of interactions with police (a public service mandated to uphold public order with the most reasonable level of force possible; IACP 2017), have arguably contributed to declining public perceptions of police legitimacy.

Public concern with police behaviour became so pressing that in December 2014 the Obama Administration assembled the President's Task Force on $21^{\text {st }}$ Century Policing (PTFCP 2015) to investigate public concerns with police accountability. Their report concluded that building trust and legitimacy was the key theme necessary for the future of successful policing in the USA. However, enhancing public perceptions of police legitimacy following the racially charged events described is challenging, particularly in a context with a longstanding race-based gap in community-police relations (Tyler 2016). Racial and ethnic minorities report lower levels of trust in police than whites, but African Americans' trust in police is especially low (Tyler 2017). These realities suggest that finding ways to improve community-police relations in general, but among racial minority and African American communities more specifically, is a high priority for enhancing public perceptions of police legitimacy.

Theories of justice offer insight on how and why positive community-police relations develop. While the outcomes of community-police encounters influence public perceptions of authorities, evidence demonstrates that the procedures used to reach outcomes wield more substantial influence on those perceptions (Lind and Tyler 1988; Tyler 2016; Tyler and Smith 1997). In the cases of Garner and McDonald, while the outcome of a citizen's death as a result of a police interaction can negatively impact public perceptions of police, it is the footage of the process leading up to the outcome-in particular, police behaviour that is unjustifiable - that most greatly compromises public perceptions of police legitimacy. Procedural justice theory offers insight on how the administration of law by police affects public perceptions of police (Latimer, Dowden, and Muise 2005; Lind and Tyler 1988; Tyler and Wakslak 2004). A key assumption of procedural justice theory is that an individual's perceptions of authorities are influenced by the treatment he receives during encounters with those authorities. Improvements in public perceptions of the legitimacy of legal authorities are a direct consequence of enhanced perceptions of procedural justice during encounters with police (Sunshine and Tyler 2003; Tyler and Wakslak 2004).

While evidence demonstrates the value of perceptions of legitimacy on support for and compliance with legal authorities, theoretical explanations of these effects are debated. Relational explanations suggest that perceptions of procedural justice and associated effects are based on the extent to which an authority's 
actions are evaluated as unbiased, trustworthy, respectful, and as offering opportunities to provide input. Attention by officers to these relational concerns prompts citizens to regard an interaction, its outcome, and legal authorities as more acceptable (Mazerolle, Bennett, Davis et al. 2013; Tyler and Degoey 1995), satisfying (Mazerolle, Bennett, Antrobus et al. 2012; Mossholder, Bennet, and Martin 1998), and legitimate (Sunshine and Tyler 2003; Tyler, Degoey, and Smith 1996; Tyler and Wakslak 2004). Alternatively, Tankebe (2013) contends that police legitimacy is a multidimensional concept comprised not only of relational but also distributive (outcome-based) concerns. However, "[s]tudies...regularly find that procedural justice is the most important antecedent of police legitimacy, with judgements about other aspects of its behaviour - notably, its effectiveness - appearing less relevant" (Bradford et al. 2014: 246). Policing that is attentive to procedural justice builds public trust in police, which enhances institutional legitimacy (Hough et al. 2010). Procedural justice concerns remain key to improving community-police relations and enhancing public perceptions of police legitimacy, despite the fact that techno-fixes currently occupy centre stage in this regard.

\section{BWCs as a Resolution to the Legitimacy Crisis}

Protests in response to the USA police-involved deaths in 2014 sparked a national discussion on race and policing that, in part, inspired the nationwide debate on police adoption of BWCs. This chain of events created the impression that police leaders were compelled to adopt BWCs, despite the reality that the technology was already receiving police attention. Tracing the genealogy of BWCs in America reveals that there are two accounts of its heritage. The prominent narrative is that police were forced to adopt BWCs due to external pressure. This explanation is observable in the language of advocacy groups such as Black Lives Matter (BLM) that maintain that police cannot hold themselves accountable and see increased police visibility as encouraging police accountability. In a 2017 Washington Post article, Ross and Lowery (2017) note that BLM members describe police adoption of BWCs as triggered by public pressure. The other narrative suggests that police acquisition of BWCs in the USA was not a result of external pressure because police began testing the cameras immediately after they hit the market in 2009 (Rice 2014; Gelles 2016) and that several agencies had adopted the technology by 2012 (White and Coldren 2017), two years before the events in 2014. This narrative suggests it was only a matter of time before BWCs became popular. This account finds support in the fact that technological advances in USA policing have historically followed the trajectory of British police forces (who first adopted BWCs in 2005; Ellis, Jenkins, and Smith 2015). A balanced version of these narratives acknowledges the role external pressure played in the expedient proliferation of a technology poised to become central to the future of policing.

As a perpetual "observer" to community-police encounters, BWCs offer a host of benefits that may help resolve the current legitimacy crisis, including improving public perceptions of police transparency and accountability (Ariel, Farrar, and Sutherland 2015; Taylor 2016; White 2014). Concerned with the state of community-police relations and subscribing to the idea that BWCs will promote community-police trust, in 2015 a federally funded program awarded $\$ 23.2$ million to police departments in thirty-two states to fund BWC programs (DOJ 2015). This initiative was part of the Obama Administration's plan to improve community-police relations (HLR 2015), initiated in response to the PTFCP recommendations (DOJ 2015). Police use of BWCs is expanding under the Trump Administration, in part, as a result of continued funding from President Trump who agrees that increased police visibility will foster community-police trust (among other desirable outcomes; DOJ 2017).

Support for BWCs also extends to civil liberties groups such as the American Civil Liberties Union (ACLU), which claims that BWCs will be a "win-win, helping protect the public against police misconduct, and at the same time helping protect police against false accusations of abuse" (Stanley 2015: 2). Blanchette and Becker (2018) maintain that this conviction is a general truism for civil liberties associations in the USA. In 2015, thirty-four civil liberties groups went public with a list of standards to guide police use of BWCs (Meyer 2015). This action suggests these groups' commitment to police adoption of BWCs. Many notable advocacy groups, including the ACLU, National Association for the Advancement of Colored People, and National Urban League, are becoming increasingly proactive in 
their effort to ensure BWCs positively impact community-police relations via policy guidelines. This commitment to establishing and vetting BWC policy in the pursuit of improved community-police relations is echoed in academic literature (Ariel 2016; Evans 2015; Feeney 2015; Palmer 2016; Taylor 2016). A common sentiment expressed by different stakeholders (e.g., government, civil liberties groups, and academics) is that much of the potential success associated with BWCs is based on their ability to positively influence public perceptions of police.

Technologies offer a means to address public concerns associated with treatment by police, ideally improving perceptions of legitimacy. Studies assessing public perceptions of BWCs consistently find that the public strongly supports police use of the technology (e.g., White, Gaub, and Todak 2016; Maskaly et al. 2017; Sousa, Miethe, and Sakiyama 2017). This line of research demonstrates that citizen support for BWCs is motivated by procedural justice concerns, with evidence suggesting that BWCs may improve perceptions of trust by enhancing perceptions of procedural justice (e.g., White, Gaub, and Todak 2016; McClure et al. 2017; McCluskey et al. 2019). Evidence of public attention to relational procedural justice concerns in relation to BWCs is building. For instance, a national survey assessing public attitudes of police use of BWCs found that eighty-six per cent polled believe that BWCs will make police behave more respectfully (Sousa, Miethe, and Sakiyama 2017). Another USA study supports this finding, revealing that approximately seventy-eight per cent of participants believed BWCs will make officers behave more professionally (White, Gaub, and Todak 2016). Citizens tend to be hopeful that BWCs will change police behaviour for the better (Maskaly et al. 2017).

However, other studies challenge this optimism. Sousa, Miethe, and Sakiyama (2017) report that only sixty-one per cent of respondents agreed that BWCs would lead to greater public trust in police. The same study found that only thirty-six per cent of respondents felt that BWCs would decrease racial tension between police and citizens. However, data on the actual effects of enhanced police visibility on community-police relations remains limited. PERF (2017) conducted a randomized controlled trial to determine the effects of BWCs on citizen perceptions of legitimacy, satisfaction with interactions, and professionalism and found no differences between the control and treatment group. This finding is consistent with results from McCarty et al.'s (2018) quasi-experimental design. Explanations for why BWCs did not affect citizen perceptions of procedural justice during their police encounters have taken different paths. McCarty et al. (2018) suggest that officer behaviour may have been consistent with procedural justice prior to the rollout of BWCs. Alternatively, PERF (2017) speculates that "implementing a BWC program is not a substitute to other activities aimed at improving citizen perceptions, such as procedural justice" (34). Rather than resolving relational justice concerns such as distrust, it may be the case that public sentiments toward BWCs are motivated more so by instrumental concerns of deterring negative officer behaviour (Timan 2016).

Similarly, civil liberties groups are increasingly communicating the challenges of resolving concerns associated with community-police relations using BWCs in isolation as demonstrated by continued involvement in the reactive policy-making process (LCCHR 2018). To date, there is little empirical evidence that speaks to how civil liberties groups' support for police use of BWCs has changed over time. However, drawing on the tendency of these groups to advocate for policy refinement as described previously, like the general public, civil liberties associations remain supportive of BWC-policing.

Despite growing inconsistencies highlighted in empirical work about the impact of BWCs on procedural justice measures, there is widespread general support among stakeholders for police use of BWCs. BWCpolicing offers the promise of enhancing community-police relations via attention to procedural justice concerns. BWC footage can be used to demonstrate transparency in critical incidents where officers act justifiably, as well as holding officers accountable for behaviour that is not deemed justifiable. Public perceptions of police legitimacy may improve if BWCs are perceived as changing or (in cases where police behaviour is deemed satisfactory) revealing the "style" of policing. The procedural justice literature indicates that policing style is critical to public perceptions of police legitimacy, particularly among communities where relations are strained (Tyler 2016). However, given the rate of public support for 
BWCs, ${ }^{1}$ even the simple act of adopting BWCs may improve public perceptions of police legitimacy in the short term.

Côté-Lussier (2013: 185) describes the importance of police attempts to enhance public perceptions of legitimacy, characterizing legitimacy as establishing "'the right thing to do' by abstracting from the specific and identifying the broader principles at hand." From this perspective, the public call for BWCs may make the decision to adopt this technology a factor that, in and of itself, enhances public perceptions of police legitimacy. However, Miller (2016) expresses that BWCs may only provide a temporary improvement in public perceptions of police legitimacy through the appearance of responsiveness. Adopting a similar perspective, we maintain that BWCs may prove useful in enhancing public perceptions of police legitimacy by making the process of policing more transparent but recognize that the technology will also capture moments when these relations could be degraded. The evolving visibility of police (Goldsmith 2010; Haggerty and Sandhu 2014) may also be detrimental to public perceptions of legitimacy, presenting the opportunity for the process by which officer decisions are reached to be scrutinized like never before-with the most contested decisions often made in volatile situations that observers later have the luxury of dissecting without turmoil and with hindsight. It is to a critical evaluation of police adoption of BWCs that we now turn.

\section{Critical Reflections on the Effects of Body-Worn Cameras on Police Legitimacy}

Advocates of BWCs suggest that these devices will "civilize" police actions and bolster police legitimacy. Yet, evaluations of BWCs (e.g., McCarty et al. 2018; Yokum, Ravishankar, and Coppock 2017; Stratton and Clissold 2015) have shown no measurable impact of BWCs on police use of force or citizen complaints. These findings question BWCs' ability to overcome the relational breakdown underlying the current legitimacy crisis through visibility alone. BWCs might more critically be conceptualized as an instance of "stochastic governance"-referring to the "governance of populations and territory by means of statistical representations based on the manipulation of Big Data" (Sanders and Sheptycki 2017: 2). Extending the surveillant assemblage, BWCs are a tool that enables the collection and monitoring of digital information on persons; a practice that is arguably positioned to become synonymous with "dataveillance" (Clarke 1988). This style of governing promotes more surveillance and creates greater relational separation between surveillance agents (as policing takes on autonomous qualities; Joh 2018) and surveillance subjects (the public generally, but marginalized communities in particular). From this perspective, BWCs are an apparatus used to "do power" rather than a neutral tool (Adams and Mastracci 2017).

It is thus important to elaborate critiques of police use of BWCs. Without a commitment to inclusionary practices, BWCs are unlikely to solve the legitimacy crisis and may exacerbate it. Instead of focusing on policies that engage with the technical aspects of BWC use, we emphasize and present more holistic initiatives to be considered in conjunction with police adoption of BWCs. These initiatives are intended to address the power imbalances that drive public concerns about police legitimacy by demonstrating attention to the relational factors that impact public perceptions of police while highlighting the ways in which BWCs could be used to address these relational concerns. We believe this focus is essential because the existing policy focus on technical use and privacy protection are likely to fall short of improving community-police relations if the relational concerns central to the current legitimacy crisis are left for BWCs to "resolve" as opposed to being directly addressed by police services.

\footnotetext{
${ }^{1}$ Research shows that the public is strongly in favor of BWCs. For example, a study by ODS Consulting (2011) shows that sixty-four per cent of Renfrewshire residents and seventy-six per cent of Aberdeen (Scotland) community members who were surveyed in 2010 favoured police adoption of BWCs. Moreover, a national survey of 4,536 American adults conducted by the Pew Research Center in 2016 found an even higher percentage (ninetythree per cent) of residents favoured BWCs (see Morin et al. 2017). A Fox6 News report by Spencer and Delong (2019) reported that a more recent poll of four hundred Wisconsin (USA) residents conducted in 2018 found a slightly higher percentage (ninety-four per cent) of Wisconsinites that favoured the cameras.
} 
Although we concentrate on critiquing the extent to which BWCs possess an independent capacity to influence public perceptions of police legitimacy, a number of additional concerns with the technology are worth acknowledging. Many of these challenges with BWCs mirror those experienced in the 1990s with public area closed-circuit television (CCTV) surveillance. First, there is an issue with cost for BWCs, data management, and administration of these surveillance systems (Fussey 2004; McCahill 2002). Public CCTV was similarly critiqued as a misuse of public funds that contributed little value to the public good. The costs of BWCs - for example, the estimated $\$ 85$ million in Toronto, Canada (Ballingall 2016) - are also generating criticism. Second, CCTVs were critiqued on the basis of efficacy, particularly whether they produce satisfactory evidentiary value (Biresi and Nunn 2003). Despite advances in camera technology, the same critiques exist of BWCs (Stalcup and Hahn 2016). Third, privacy implications were a central concern associated with CCTVs (Norris, McCahill, and Wood 2004), and this concern is accentuated in the realm of BWCs with their advanced data collection capabilities, including biometric (Otu 2016; Coudert, Butin, and Le Métayer 2015). Fourth, the common surveillance studies concern with "social sorting" (Lyon 2005) is relevant here, with the potential for increased marginalization of groups that police monitor more closely with such technologies (Coleman 2004; Williams and Johnstone 2000). Fifth, the adoption of public CCTV raised questions about why the technology was needed at all given the resources police already had at their disposal, and BWCs have likewise been called a solution in search of a problem (Palmer 2016). As with many technological changes in policing, there is reason to be cautious of innovations. Finally, there are questions about whether this type of surveillance does anything to change community-police relations - potentially enhancing public perceptions of police transparency and accountability or further alienating police from the communities they serve (Fussey 2004; Coleman and Sim 2000). Drawing on Sanders and Sheptycki's (2017) concept of stochastic governance, the latter seems more likely to occur than the former (see Joh 2018), making it even more important for police to be attentive to relational concerns in the era of BWCs.

BWCs may impact public perceptions of police legitimacy (both positively and negatively), particularly in marginalized communities. Ray, Marsh, and Powelson (2017) found that racialized groups are less likely to believe implementation of BWCs will make police more accountable or transparent. In this way, BWCs may act as tools that entrench antagonistic relations with marginalized communities. This runs counter to optimistic accounts that conceptualize BWCs as increasing public perceptions of police legitimacy. Investigating the intersectional dimensions of the effects of BWCs on public perceptions of legitimacy (in line with Brown's (2015) call for examinations of how racial and ethnic marginalization, as well as class inequality, intersect with policing's new visibility) is an essential direction for future research. Another consideration is the implications of this new form of visibility on the exposure and visualization of victims. As Adams and Mastracci (2017) argue, BWC footage of victims of crime and victims of police shootings can be shared or broadcast without victim or family consent in ways that can re-victimize those persons and their families. Re-victimization may diminish perceptions of procedural justice via antecedents such as respect and voice.

Furthermore, perceptions of police legitimacy may also be affected by internal police administrative procedures. Stalcup and Hahn (2016) note that, in some cases, footage is mysteriously missing or cameras are conspicuously turned off before events unfold; Willits and Makin (2017) contend that BWC footage often fails to reveal crucial aspects of events; and, Vitale (2017) argues that BWC footage should be under the control of a neutral third party. All these issues may leave the public questioning the trustworthiness of police, highlighting public feelings of alienation from the decision-making process associated with BWCpolicing. Beyond that, the technology has been shown to fail, notably because of faulty batteries as experienced by Toronto Police Service (CBC 2017). Calgary Police Service took their original BWC supplier to court over technical failures that compromised officer and public safety (Dormer 2017). A concerning finding is that police agencies that have adopted technological surveillance systems in the past are more likely to do so in the future (Nowacki and Willits 2016), suggesting there may be a rush to implement such new technologies, which is troubling given that there is currently minimal oversight for ensuring that use of BWCs follows best practices. Barbour (2017) argues that there must be judicial and statutory level reform to ensure best practices in information storage and handling of BWC data (also see 
Pagliarella 2016). Public expectations and police use of BWCs are less likely to find common ground without legislative and judicial guidelines for both to defer to, and such discrepancies are likely to result in a negative impact on public perceptions of police.

Even when such guidelines are in place, some may view BWCs as inherently favouring the perspective of police. When the cameras are rolling, Sandhu (2017) reports that police often undertake efforts to be seen, with officers in his research describing the strategic benefit of getting in front of a camera while working. Such benefits include the advantage of laying the groundwork for "professional vision"- "socially organized ways of seeing and understanding events that are answerable to the distinctive interests of a particular social group" (Goodwin 1994: 606) - that can be asserted should the footage make it to the courtroom. In a complementary vein, Brucato (2015) notes that police use of excessive force is not mitigated by visibility. He argues that police shootings have only increased during this era of new police visibility. Framed through this lens, what is important to investigate is how video footage is interpreted, how alternative interpretations of video recordings are discredited, and how institutional power is distributed and maintained. This begs further empirical investigation of the relationship between BWCs, visibility, and public perceptions of police legitimacy.

While research tends to focus on the ways in which BWCs improve public perceptions of police, empirical work also demonstrates how BWC footage might negatively affect public perceptions of police. A study examining citizens' perceptions of police shootings conducted before the death of Michael Brown found that respondents were more likely to report the shooting was justified when evidence of the encounter was presented in video or audio format compared to a text format (Culhane, Boman, and Schweitzer 2016). This finding suggests that BWCs would enhance public perceptions of police legitimacy. However, a replication of this study following Brown's death found that respondents presented with evidence in video format, compared to audio or text format, were more likely to report that the shooting was unjustified (McCamman and Culhane 2017). These findings lend support to Sommers's (2015) conclusion that mockjurors' evaluations of police actions are shaped by pre-existing attitudes toward police. Rather than the footage rendering truth, footage renders a visual image that is interpreted in relation to a variety of factors. This reality could prompt the new visibility of officers to compromise rather than enhance public perceptions of police (and other legal authorities) legitimacy even when police act justifiably.

The relational consequences of enhanced citizen visibility during police interactions are also debatable. For Brighenti (2007), visibility is a generic social process connected to recognition and control. Visibility is connected to recognition insofar as being visible is a means of being seen and valued. Visibility is, at the same time, connected to control in all the ways that are familiar to surveillance studies scholars. For Brighenti, the concept of visibility is relational and at times paradoxical. Procedural justice theory is complementary to this understanding of visibility. Whether visibility entails recognition or control involves the communication of relational messages akin to those that drive perceptions of procedural justice. Some visualization can entail recognition and control for a party simultaneously, as would seem to be the case with multiple interpretations of video footage, for example, the notable cleavage between police interpretations that treat footage as an exoneration and public interpretations that see footage as proof of guilt in contested cases of police misconduct (Schneider 2016). Brighenti (2007: 339) further argues that there are different types of visibility schemes, one of which is the "media type"-referring to when information is subject to decontextualization - "whereby subjects are isolated from their original context and projected into a different one endowed with its own logic and rules." We contend that BWC footage is usefully conceived as a media type of visibility insofar as the footage is often contested and becomes subject to claims-making and discursive struggles. This critique confronts the idea of "forensic accuracy" (Goldsmith 2010: 931) tethered to new surveillance technologies that police deploy. Instead, the outputs of these devices do not tend to be singularly understood but are visualized in a multiplicity of ways to convince, lure, assemble, and draw together networks that reinforce certain understandings of the information and not others (Latour 1990). For instance, Schneider (2018) argues that BWC footage often serves to augment police narratives and interpretations of events. The same footage that can be used to condemn an officer can also be used to justify and explain his actions. While non-police are permitted to 
question the interpretation and sequence of actions, public police, as the initial "owners" of BWC footage, may be perceived as having a monopoly on interpreting recordings.

This ability of the police to govern interpretations of visual footage is not new. As Goodwin (1994) demonstrates in his analysis of the defense interpretation of footage of the Rodney King beating, the claims made seem almost preposterous. Yet these claims can stick and be treated as truth. Certainly, the footage from BWCs has failed to secure successful prosecutions in several high-profile police shooting cases in the USA (Lopez 2017) in a manner that demonstrates Goodwin's (1994) concept of professional vision. It is not the footage itself or the cameras that are the problem but the broader apparatus of power that allows dubious interpretations to be advanced by legal authorities. These claims can backfire and undermine public perceptions of police legitimacy, as the riots following the ruling in the Rodney King case illustrate.

This production of professional vision is an underlying problem to using BWCs in the hopes of improving poor community-police relations that should be a focus of continued critique. Professional vision (Goodwin 1994) encompasses the institutional apparatus (from media framings, to lawyers, to online social media users) that can all serve to reinforce power imbalances that continue to fracture communitypolice relations. BWCs are, in part, intended to serve as public relations and communications management devices, but we argue that they sidestep rather than directly resolve poor community-police relations. Without attention to the implications of BWC-policing on relational concerns, BWC footage is merely plugged into the existing circuitry of power. This reality is well illustrated by the police-involved shooting death of Loreal Tsingine, a 27-year-old Navajo woman, in Winslow, Arizona.

Tsingine was killed on March 27, 2016, after she approached an officer during a confrontation that was captured with a BWC. Tsingine fit the description that a convenience store clerk gave police of someone recently in the store. The officer claimed that he felt threatened by Tsingine who was holding a small pair of scissors when she was shot. Navajo and other Indigenous communities protested the shooting. Four months after the shooting, the Maricopa County Attorney's office decided not to file criminal charges against the officer, Michael Shipley. The BWC footage was part of the material reviewed in reaching this decision. The officer was placed on paid leave. In October 2016, an Internal Affairs investigation by Mesa Police Department (MPD) concluded. The officer resigned after completion of the MPD Internal Affairs investigation, although not all records and deliberations have been shared with the public (Blackhorse 2017). During the investigation, it was revealed that Shipley had twice been written up (but not reprimanded) for abusive conduct in his career (Baca 2016).

The BWC footage was then released, showing Shipley rapidly discharging his weapon five times into the torso of Tsingine. The footage shows Shipley being aggressive with Tsingine prior to the shooting. The footage shows another officer at the scene; the other officer was standing near to Tsingine and was poised to assist. Instead, Shipley released a volley of shots. The whole encounter, from the time Shipley gets out of his car, to the confrontation and moment when Shipley shoves Tsingine to the ground, to the moment Tsingine approaches Shipley and he fires his weapon, takes thirty-five seconds. The autopsy would later show that two of the shots hit Tsingine in the back. When asked why he shot Loreal Tsingine in the back, Shipley said he did not realize Tsingine had been spun around while falling after the first shots (Jeong 2016a). It was also found that Shipley knew Tsingine from previous encounters (despite denying this) and that he had a history of confrontations with Indigenous persons (Jeong 2016b). Navajo and other Indigenous communities continued to protest the decision, including in other cities throughout Arizona, and family members submitted a wrongful death claim on behalf of Tsingine's daughter.

It is important to note what the BWC did and did not do during the encounter between Tsingine and Shipley. The BWC did not generate appropriate use of force by the officer. The officer shows no restraint or professionalism. However, the release of the footage did have implications on public perceptions of police, showing to the public how poorly, violently, and amateurishly this officer acted. It also may decrease public perceptions of police oversight by revealing the inadequacy of accountability measures in 
the face of visual evidence showing the improper conduct of the officer. In this case, the footage did not produce revelations that left all parties satisfied. Instead, this is an instance demonstrative of professional vision (Goodwin 1994) of the MPD and the Maricopa County Attorney's office deviating from and dominating the interpretations of other public groups.

Just as the police-shootings of unarmed African American men in the USA must be placed in the broader context of slavery and ethnic and racial antagonism, the shooting of Tsingine should be placed in the context of ongoing colonial relations between settlers and Indigenous persons, including notable tensions between residents of Winslow and Mesa and Navajo persons. The event garnered enough attention that the DOJ held consultations in the Navajo Nation after the shooting and promised to launch an inquiry. When that inquiry did not transpire, the Navajo Nation Human Rights Commission organized their own inquiry into the shooting of Tsingine and violence against Indigenous peoples by the police as well as other settlers. Police violence became a central focus of the inquiry, with the shooting of Tsingine and the visualization of it via the BWC footage becoming an entry point into contemplating the history of colonial violence in the region. The events and the handling of the case and footage resulted in the Navajo Nation Human Rights Commission (2017) and other Indigenous groups taking the responsibility for justice into their own hands, due to the failures of the official justice system to reconcile these harms. These actions underscore the influence of vicarious police experience in the formation of perceptions toward police (Rosenbaum et al. 2005), which prompt public perceptions of police legitimacy as well as the criminal justice system to suffer. Public perceptions are affected not only by the conduct of the officer but also legal authorities' backing of Shipley's interpretation of the events despite damning footage (mirroring the case of Laquan McDonald). The case is illustrative of police attempts to manage the account of the events and the fallout, not an actual effort to do policing differently (Ericson 1989). The case is also demonstrative of what Brighenti (2007) calls the relational, paradoxical nature of visibility. The footage is used in a way that recognizes the police account and discounts other interpretations, such that criminal charges are never laid. At the same time, it engenders attempts at regulation and control of police conduct and a dislodging of the official justice system as the appropriate place of truth and reconciliation.

The introduction of BWCs, which proponents suggest will collect objective recordings, is the most notable recent attempt to address police misconduct and democratize the truth-making and reconciliation process in the American justice system. The public, police, and the justice system in general stand to benefit greatly should BWCs lead to these changes. These outcomes would likely strengthen public perceptions of police legitimacy. However, it is unlikely that BWCs will have positive impacts on community-police relations if they are not accompanied by a broader commitment to inclusionary policing practices. Recognizing that BWCs are central to the immediate future of policing, we recommend that police agencies incorporate relationally minded considerations alongside techno-fixes to enhance the positive capabilities of police use of BWCs. To encourage this, we outline two inclusionary initiatives that we propose be implemented by a joint task force of officers and community members.

\section{Initiative 1: Stakeholder Trust Building}

The vision for this program is that officers and citizens form a long-term working partnership to assess community and police concerns about police use of BWCs, making semi-annual recommendations for addressing them. Achieving this goal will require police and citizens to strike a balance between their respective views on how departments' BWC programs should be operated. A focus of the team should be justice concerns (addressing expectations and operational measures of success from both perspectives). We also recommend that special attention be given to officer concerns related to the practical use of BWCs. The team should work to identify any disconnects between BWC policy and applied use. Although we advocate that attention be given to technical concerns, we do advise that the team make recommendations for optimizing BWCs that are not technologically based. In doing so, the team will be forced to give significant attention to the relational concerns that need to be addressed to create trusting relationships among BWCs stakeholders, namely between police and the public. 
To facilitate knowledge acquisition, the team should regularly collect data from citizens and officers using open meetings, social media, and community engagement activities. To identify potential disconnects between policy and practice, the team should use thoughtfully selected recordings. However, to enhance officer perceptions of trust, officers whose recordings are pulled should be recruited (or incentivized) to partake in the process. To encourage officer participation, the team should establish an anonymous BWCconcern reporting system.

With officer consent, citizens whose recordings are used should also be recruited to partake in the process. While securing officer consent is a safety measure, it also provides opportunities to sense the level of community-police trust, assuming that more trust will increase the likelihood of officers agreeing to have citizens involved in the process. While the responsibility of compiling and assessing data and recommending ways to integrate BWCs into policing should be shouldered by core members of the program, we recommend that the team seeks public and officer (department-wide, not only those whose videos are selected) participation in the assessment and recommendation phase. Although departments can make participation mandatory, we suggest that agencies use incentives as a less coercive approach for encouraging participation. While the recommendations made by the team will be important to the success of this initiative, the degree to which the team engages the public and officers and the harmonization of community-police concerns should also serve as performance measures.

\section{Initiative 2: BWC and Community Policing Fusion Assessment}

The second initiative that we recommend is that police organizations create a committee to assess the degree to which BWC use and policy are in line with the goals of community policing. We recommend that this initiative is operated by a mixed group of patrol officers, citizens, and frontline police supervisors. The participating officers and citizens should work with each other to identify incongruences between departmental community policing goals and BWC policy. These incongruences may be observable in several areas. For example, a critical analysis of the implementation of BWCs in the North Carolina Police Department concludes that the program deviates from the goals of community policing because policy guidelines

create nebulous expectations for police behaviour and fail to acknowledge power asymmetries. Furthermore, the video access statutes grant significant discretion to the police department and its officers but limit public oversight. Finally, the asset forfeiture funds used to finance the program might spell exploitation [for marginalized communities]. (Ramachandran 2017: 7)

We again recommend that this initiative is pursued indefinitely on the basis that community policing is built on the foundation of responsiveness to community needs; as new community needs emerge, it is important that BWCs be integrated into the problem-solving process. The initiative team should produce a semi-annual report noting their discoveries and recommendations for what needs to be done to address or fuse goals, guidelines, and practices of police use of BWCs with community policing. In addition to analyzing policy documents, this initiative team should collect data from police and citizens, as well as conducting evaluations of programs designed to improve community-police relations while reflecting specifically on how to integrate BWCs into such programs in the interest of furthering that objective.

While both initiatives may prove to be effective on their own, we recommend that they are implemented as a package because they feed into each other. While the reports should be helpful in efforts to optimize BWCs, the main purpose is to provide organizations with information that improves community-police relations. Together, these initiatives are designed to be inclusionary in the sense that citizens and frontline officers represent their own voice in the process. While democratic practices suggest that citizens and police will participate in the process, participation may only include a single or a few instances of the two parties voicing their opinions through surveys, non-recurring meetings, or having their voices represented by a few representatives in the process. Recognizing the difficulty such approaches will undoubtedly encounter in improving community-police relations, we have suggested that these two programs facilitate 
an active and continuous working relationship between police and citizens. By establishing an intimate working relationship, the team will improve its ability to garner participation from citizens and officers via recruitment and voluntary involvement.

The success of BWC-policing is, in part, a question of whether BWC use and interpretation of footage satisfy public concerns with procedural justice. In terms of neutrality, the public demands decision-makers who follow rules and apply those rules consistently. In terms of respect, people want to be treated with dignity and as serious stakeholders in the adoption of new practices. In terms of trustworthiness, the public wants to observe decision-makers who consider the views of all in the interest of reaching benevolent decisions. In terms of voice or participation, the public wants to be able to have their side of a story heard before decisions are made. Within the context of community policing, procedural justice also means that the public and patrol officers wish to be continually involved in processes related to BWCs. In cases where officers are captured engaging in unjustifiable conduct, where police and legal authorities interpret such BWC footage as justifiable using their own professional vision, and in scenarios where police messaging trumps the voices of victims of police violence, the core elements of procedural justice are not satisfied. The double-edged nature of visibility will undermine police efforts to ensure the generation of legitimacy through devices like BWCs that equate visibility with trust if police organizations do not also work to improve community-police relations through a broader range of inclusionary police practices.

\section{Conclusion}

An international spotlight has been cast on police in America as a result of a succession of police-involved killings of unarmed citizens that began gaining notoriety in 2014. While these killings have been concentrated in African American communities, other marginalized communities such as Latinos and Indigenous peoples have also been impacted by police misconduct and violence. The plan to quell the violence and the associated legitimacy crisis has been tethered to BWCs. The assumption driving BWC implementation is that these devices will make police more transparent, accountable, and trustworthy, leading to enhanced perceptions of police legitimacy. Legitimacy is perhaps the most important issue for policing in democracies in the twenty-first century (Jones and Newburn 2002). In that pursuit, BWCs may enhance public trust and confidence in police. However, techno-fixes by themselves will not resolve underlying issues of fractured community-police relations, including ongoing issues of racial and ethnic antagonism and colonialism, and may even exacerbate these tensions. True reform requires establishing bonds of trust between communities and police that acknowledge the importance of procedural treatment, which may be supported by - but are not dependent on-BWCs.

Police use of BWCs will do little to improve public perceptions of police legitimacy if not supplemented with inclusionary programs. The implications of this are far-reaching, as more police in the USA and elsewhere adopt BWCs (Fan 2016). Prioritizing community-police relations alongside the early adoption of BWCs is key. Vendors are already adjusting the technology (e.g., facial recognition capabilities) (LCCHR 2018) in ways that may negatively affect community-police relations, thus enhancing social distance between police and citizens and diminishing trust between persons unless technological confirmation is attained. In addition to these concerns, this pattern of practice is problematic for the sustainability of police reform in that it negatively impacts policy-making and evaluation. This is, in part, because the police profession and technology are both dynamic, making the policy-making process more of a reactive than a proactive response (Alpert and Smith 1994) and thus, always a step or more behind addressing concerns that threaten community-police trust. The constantly changing nature of policing generates a plethora of changes in policy and procedures (which may or may not be congruous with existing guidelines), making it difficult for scholars and practitioners to track and assess the impact of reform efforts in the long run (Walker 2012). This is concerning because it is essential that BWC policies be designed to complement the goals of community policing. However, BWC policy guidelines can and do deviate from the goals of community policing (Ramachandran 2017). The initiatives we recommend prioritize community policing practices alongside the adoption of BWCs in the interest of addressing the relational concerns underlying the power imbalances characterizing the current police legitimacy crisis. 


\section{References}

Adams, Ian, and Sharon Mastracci. 2017. Visibility is a Trap: The Ethics of Police Body-Worn Cameras and Control. Administrative Theory \& Praxis 39 (4): 313-28.

Alpert, Geoffrey P., and William C. Smith. 1994. Developing Police Policy: An Evaluation of the Control Principle. American. Journal of Police 13 (2): 1-19.

Ariel, Barak. 2016. The Puzzle of Police Body Cams. IEEE Spectrum 53 (7): 32-37.

Ariel, Barak, William A. Farrar, and Alex Sutherland. 2015. The Effect of Police Body-Worn Cameras on Use of Force and Citizens' Complaints Against the Police: A Randomized Controlled Trial. Journal of Quantitative Criminology 31 (3): 509 35 .

Baca, Kim. 2016. Officer Who Killed Loreal Tsingine Resigns Following Investigation. Indian Country Media Network, November 3, 2016. https://newsmaven.io/indiancountrytoday/archive/officer-who-killed-loreal-tsingine-resigns-followinginvestigation-QrnThAQiFkmmGHjHmpewIQ/ [accessed January 12, 2018].

Ballingall, Alex. 2016. Questions Linger Over Steep Cost of Police Body Cameras. Toronto Star, September $18,2016$. https://www.thestar.com/news/gta/2016/09/18/questions-linger-over-steep-cost-of-police-body-cameras.html [accessed January 11, 2018].

Barbour, Bradley X. 2017. Big Budget Productions with Limited Release: Video Retention Issues with Body-Worn Cameras. Fordham Law Review 85 (4): 1,724-755.

Biressi, Anita, and Heather Nunn. 2003. Video Justice: Crimes of Violence in Social/Media Space. Space and Culture 6 (3): 27691.

Blackhorse, Amanda. 2017. One Year Later, and Still No Justice for Loreal Tsingine. Indian Country Media Network, April 14, 2017. $\quad$ https://indiancountrymedianetwork.com/culture/social-issues/blackhorse-one-year-later-still-no-justice-lorealtsingine/ [accessed January 15, 2018].

Blanchette, Jean-François, and Snowden Becker. 2018. Bodycam Footage as Document: An Exploratory Analysis. In Transforming Digital Worlds: iConference 2018 (proceedings), edited by Gobinda Chowdhury, Julie McLeod, Val Gillet, and Peter Willett, 609-14. Cham, CH: Springer.

Bradford, Ben, Aziz Huq, Jonathan Jackson, and Benjamin Roberts. 2014. What Price Fairness when Security Is at Stake? Police Legitimacy in South Africa. Regulation \& Governance 8 (2): 246-68.

Brighenti, Andrea. 2007. Visibility: A Category for the Social Sciences. Current Sociology 55 (3): 323-42.

Brown, Gregory R. 2016. The Blue Line on Thin Ice: Police Use of Force Modifications in the Era of Cameraphones and YouTube. British Journal of Criminology 56 (2): 293-312.

Brucato, Ben. 2015. Policing Made Visible: Mobile Technologies and the Importance of Point of View. Surveillance \& Society 13 (3/4): 455-73.

CBC (Canadian Broadcasting Corporation). 2017. Build Us a Body-Worn Camera with Technology 'That Doesn't Fail,' Toronto Police Tell Manufacturers. CBC News, October 17, 2017. http://www.cbc.ca/news/canada/toronto/toronto-body-worncameras-police-technology-1.4357773 [accessed January 11, 2018].

Clarke, Roger. 1988. Information Technology and Dataveillance. Communications of the ACM 31 (5): 498-512.

Coleman, Roy. 2004. Reclaiming the Streets: Closed Circuit Television, Neoliberalism and the Mystification of Social Divisions in Liverpool, UK. Surveillance \& Society 2 (2/3): 294-309.

Coleman, Roy, and Joe Sim. 2000. 'You'll Never Walk Alone:' CCTV Surveillance, Order and Neo-liberal Rule in Liverpool City Central. British Journal of Sociology 51 (4): 623-39.

Côté-Lussier, Carolyn. 2013. Narratives of Legitimacy: Police Expansionism and the Contest over Policing. Policing and Society 23 (2): 183-203.

Coudert, Fanny, Denis Butin, and Daniel Le Métayer. 2015. Body-Worn Cameras for Police Accountability: Opportunities and Risks. Computer Law \& Security Review 31 (6): 749-62.

Culhane, Scott E., John H. Boman IV, and Kimberly Schweitzer. 2016. Public Perceptions of the Justifiability of Police Shootings: The Role of Body Cameras in a Pre- and Post-Ferguson Experiment. Police Quarterly 19 (3): $251-74$.

Davis, Angela J. 2007. Arbitrary Justice: The Power of the American Prosecutor. Oxford: Oxford University Press.

DOJ (Department of Justice). 2015. Justice Department Awards over \$23 Million in Funding for Body Worn Camera Pilot Program to Support Law Enforcement Agencies in 32 States. Department of Justice News, September $21,2015$. https://www.justice.gov/opa/pr/justice-department-awards-over-23-million-funding-body-worn-camera-pilot-programsupport-law [accessed January 17, 2018].

Dormer, Dave. 2017. Calgary Police to Sue Original Supplier as Search Continues for Body Cameras. CBC News Calgary, September 5, 2017. https://www.cbc.ca/news/canada/calgary/calgary-police-body-worn-cameras-1.4275720 [accessed January 12,2018$]$.

Ellis, Tom, Craig Jenkins, and Paul Smith. 2015. Evaluation of the Introduction of Personal Issue Body Worn Video Cameras (Operation Hyperion) on the Isle of Wight: Final Report to Hampshire Constabulary. https://researchportal.port.ac.uk/portal/en/publications/evaluation-of-the-introduction-of-personal-issue-body-worn-videocameras-operation-hyperion-on-the-isle-of-wight(aa564df2-ffda-4b72-b0b6-7f9cb823aa77).html [accessed June 22, 2016].

Ericson, Richard V. 1989. Patrolling the Facts: Secrecy and Publicity in Police Work. British Journal of Sociology 40 (2): 20526.

Evans, Danielle. 2015. Police Body Cameras: Mending Fences and How Pittsburgh is a Leading Example. Pittsburg Journal of Technology, Law \& Policy 16 (1): 76-100.

Fan, Mary D. 2016. Justice Visualized: Courts and the Body Camera Revolution. University of California, Davis, Law Review (3): 897-959. 
Feeney, Matthew. 2015. Watching the Watchmen: Best Practices for Police Body Cameras. Washington, DC: Cato Institute. https://www-cato-org.proxy.cc.uic.edu/publications/policy-analysis/watching-watchmen-best-practices-police-bodycameras [accessed February 11, 2018].

Fussey, Pete. 2004. New Labour and New Surveillance: Theoretical and Political Ramifications of CCTV Implementation in the UK. Surveillance \& Society 2 (2/3): 251-69.

Gelles, David. 2016. Taser International Dominates the Police Body Camera Market. New York Times, July $12,2016$. https://www.nytimes.com/2016/07/13/business/taser-international-dominates-the-police-body-camera-market.html [accessed June 13, 2018].

Goldsmith, Andrew John. 2010. Policing’s New Visibility. British Journal of Criminology 50 (5): 914-34.

Gonzales, Alberto R., and Donald Q. Cochran. 2017. Police-Worn Body Cameras: An Antidote to the Ferguson Effect. Missouri Law Review 82 (2): 299-338.

Goodwin, Charles. 1994. Professional Vision. American Anthropologist 96 (3): 606-33.

Haggerty, Kevin D., and Ajay Sandhu. 2014. The Police Crisis of Visibility [Commentary]. IEEE Technology and Society Magazine 33 (2): 9-12.

Hayes, Jonathan, and Lars Ericson. 2012. A Primer on Body-Worn Cameras for Law Enforcement. Washington, DC: National Institute of Justice. https://www.justnet.org/pdf/00-Body-Worn-Cameras-508.pdf [accessed March 12, 2017$].$

HLR (Harvard Law Review). 2015. Considering Police Body Cameras. Harvard Law Review 128 (6): 1,794-817. https://harvardlawreview.org/2015/04/considering-police-body-cameras/ [accessed May 20, 2017]

Hough, Mike, Jonathan Jackson, Ben Bradford, Andy Myhill, and Paul Quinton. 2010. Procedural Justice, Trust, and Institutional Legitimacy. Policing: A Journal of Policy and Practice 4 (3): 203-10.

IACP (International Association of Chiefs of Police). 2017. National Consensus Policy and Discussion Paper on Use of Force. Alexandria, VA: IACP. http://www.theiacp.org/Portals/0/documents/pdfs/National Consensus Policy On Use Of Force.pdf [accessed January $23,2018]$.

Jackson, Jonathan, Ben Bradford, Mike Hough, Andy Myhill, Paul Quinton, and Tom R. Tyler. 2012. Why Do People Comply with the Law? Legitimacy and the Influence of Legal Institutions. British Journal of Criminology 52 (6): 1,051-071.

Jameel, Leila, and Sarah Bunn. 2015. Body-Worn Video in UK Policing. London: Parliamentary Office of Science and Technology. https://researchbriefings.parliament.uk/ResearchBriefing/Summary/POST-PB-0014 [accessed June 11, 2017].

Jeong, Yihyun. 2016a. The Death of Loreal Tsingine, As Told By the Winslow Police Officer Who Shot Her. Arizona Central, November 18, 2016. https://www.azcentral.com/story/news/local/arizona/2016/11/18/arizona-death-loreal-tsingine-as-toldby-winslow-police-officer-austin-shipley/94048074/ [accessed December 17, 2018].

Jeong, Yihyun. 2016b. Winslow Body-Camera Video Shows Fatal Shooting. Arizona Central, November $18,2016$. https:/www.azcentral.com/story/news/local/arizona/2016/07/27/winslow-body-camera-video-shows-fatalshooting/87625554/[accessed December 17, 2018].

Joh, Elizabeth E. 2018. Automated Policing. Ohio State Journal of Criminal Law 15: 559-63. https://papers.ssrn.com/sol3/papers.cfm?abstract id=3150651 [accessed May 24, 2018].

Jonathan-Zamir, Tal, Badi Hasisi, and Yoram Margalioth. 2016. Is It the What or the How? The Roles of High-Policing Tactics and Procedural Justice in Predicting Perceptions of Hostile Treatment: The Case of Security Checks at Ben-Gurion Airport, Israel. Law \& Society Review 50 (3): 608-36.

Jones, Trevor, and Tim Newburn. 2002. The Transformation of Policing? Understanding Current Trends in Policing Systems. British Journal of Criminology 42 (1): 129-46.

Latimer, Jeff, Craig Dowden, and Danielle Muise. 2005. The Effectiveness of Restorative Justice Practices: A Meta-Analysis. Prison Journal 85 (2): 127-44.

Latour, Bruno. 1990. Visualisation and Cognition: Drawing Things Together. In Representation in Scientific Practice, edited by Michael Lynch and Steve Woolgar, 19-68. Cambridge, MA: MIT Press. http://www.bruno-latour.fr/sites/default/files/21DRAWING-THINGS-TOGETHER-GB.pdf [accessed June 20, 2019].

LCCHR (Leadership Conference on Civil and Human Rights). 2018. Letter to Axon AI Ethics Board Regarding Ethical Product Development and Law Enforcement. LCCHR (letter), April 26, 2018. https://civilrights.org/resource/axon-productdevelopment-law-enforcement/ [accessed May 5, 2018].

Lind, E. Allan, and Tom R. Tyler. 1988. The Social Psychology of Procedural Justice. Amsterdam: Springer Science \& Business Media.

Lopez, German. 2017. The Failure of Police Body Cameras. Vox, July 21, 2017. https://www.vox.com/policy-andpolitics/2017/7/21/15983842/police-body-cameras-failures [accessed December 16, 2018].

Lyon, David. 2005. Surveillance as Social Sorting: Computer Codes and Mobile Bodies. In Surveillance as Social Sorting: Privacy, Risk, and Digital Discrimination, edited by David Lyon, 27-44. London: Routledge.

Maskaly, Jon, Christopher Donner, Wesley G. Jennings, Barak Ariel, and Alex Sutherland. 2017. The Effects of Body-Worn Cameras (BWCs) on Police and Citizen Outcomes: A State-of-the-Art Review. Policing: An International Journal of Police Strategies \& Management 40 (4): 672-88.

Mazerolle, Lorraine, Sarah Bennett, Emma Antrobus, and Elizabeth Eggins. 2012. Procedural Justice, Routine Encounters and Citizen Perceptions of Police: Main Findings from the Queensland Community Engagement Trial (QCET). Journal of Experimental Criminology 8 (4): 343-67.

Mazerolle, Lorraine, Sarah Bennett, Jacqueline Davis, Elise Sargeant, and Matthew Manning. 2013. Procedural Justice and Police Legitimacy: A Systematic Review of the Research Evidence. Journal of Experimental Criminology 9 (3): 245-74.

McCahill, Mike. 2002. The Surveillance Web: The Rise of Visual Surveillance in an English City. Cullompton, UK: Wilan. 
McCamman, Michael, and Scott Culhane. 2017. Police Body Cameras and Us: Public Perceptions of the Justification of the Police Use of Force in the Body Camera Era. Translational Issues in Psychological Science 3 (2): 167-75.

McCarty, William P., Ermus St. Louis, Gina Enciso, Alana Saulnier, Mariana Palacios, Zhe Meng, Justin Escamilla, Erin Sheridan, Emmanuel Bates, Tony Liu, Jivak Shah, and Kristen Trandai. 2018. An Evaluation of the Chicago Police Department's Body-Worn Camera Program. Unpublished report, available upon request.

McClure, Dave, Nancy La Vigne, Mathew Lynch, Laura Golian, Daniel Lawrence, and Aili Malm. 2017. How Body Cameras Affect Community Members' Perceptions of Police: Results from a Randomized Controlled Trial of One Agency's Pilot. Washington, DC: Urban Institute. https://www.urban.org/sites/default/files/publication/91331/2001307-how-body-camerasaffect-community-members-perceptions-of-police 2.pdf [accessed March 17, 2018].

McCluskey, John D., Craig D. Uchida, Shellie E. Solomon, Alese Wooditch, Christine Connor, and Lauren Revier. 2019. Assessing the Effects of Body Worn Cameras on Procedural Justice in the Los Angeles Police Department. Criminology 57 (2): 208-36.

Meyer, Robin. 2015. The People's Manifesto on Police Body-Cameras: New Guidelines About How Law Enforcement Should Implement Wearable Cameras from a Coalition of Nearly Three Dozen Civil-Rights Groups. Atlantic, May 15, 2015. https:/www.theatlantic.com/technology/archive/2015/05/civil-rights-rules-for-body-cameras/393377/ [accessed May 12, 2018].

Miller, Kirk. 2016. Watching the Watchers: Theorizing Cops, Cameras, and Police Legitimacy in the 21st Century. In The Politics of Policing: Between Force and Legitimacy, edited by M. Deflem, 257-76. Bingley, UK: Emerald Group.

Morin, Rich, Kim Parker, Renee Stepler, and Andrew Mercer. 2017. Behind the Badge. Washington, DC: Pew Research Center. www.pewresearch.org [accessed June 21, 2017].

Mossholder, Kevin W, Nathan Bennett, and Christopher Martin. 1998. A Multilevel Analysis of Procedural Justice Context. Journal of Organizational Behavior 19 (2): 131-41.

Murphy, Kristina. 2014. Procedural Justice, Legitimacy, and Policing. In Encyclopedia of Criminology and Criminal Justice, edited by Gerben Bruinsma and David Weisburd, 4,024-034. Cham, CH: Springer. https://link-springercom.proxy.cc.uic.edu/content/pdf/10.1007/978-1-4614-5690-2 65.pdf [accessed May 17, 2017].

Navajo Nation Human Rights Commission. 2017. The Navajo Nation Human Rights Commission and UNM Institute for American Indian Research Convene a Panel: An Inquiry into the Death of Loreal Tsingine, Human Rights Challenges to Police, and Border Town Violence Against Indigenous Women and Peoples. Press Release, Office of Navajo Nation Human Rights Commission, October 2, 2017. St. Michaels, AZ: NNHRC. http://www.nnhrc.navajonsn.gov/PressReleases/2017/October/PR_10022017.pdf [accessed January 12, 2018].

Norris, Clive, and Michael McCahill. 2005. CCTV: Beyond Penal Modernism? British Journal of Criminology 46 (1): $97-118$.

Norris, Clive, Mike McCahill, and David Wood. 2004. The Growth of CCTV: A Global Perspective on the International Diffusion of Video Surveillance in Publicly Accessible Space. Surveillance \& Society 2 (2/3): 110-35.

Nowacki, Jeffrey S, and Dale Willits. 2016. Adoption of Body Cameras by United States Police Agencies: An Organisational Analysis. Policing and Society 28 (7): 841-53.

ODS (Organisational Development and Support) Consulting. 2011. Body Worn Video Projects in Paisley and Aberdeen, Self Evaluation. Glasgow: ODS Consulting. http://www.bwvsg.com/wp-content/uploads/2013/07/BWV-Scottish-Report.pdf [accessed April 14, 2017].

O’Neil, Lauren. 2013. Sammy Yatim Murder Charge Sparks Strong Reaction Among Canadians-Your Community. CBC News, August 19, 2013. http://www.cbc.ca/newsblogs/yourcommunity/2013/08/sammy-yatim-murder-charge-sparks-strongreaction-from-canadians.html [accessed April 14, 2017].

Otu, Noel. 2016. Police Body Cameras: Seeing May Be Believing. Critical Essays 4 (3): 49-64.

Pagliarella, Chris. 2016. Police Body-Worn Camera Footage: A Question of Access. Yale Law \& Policy Review 34 (2): 533.

Palmer, Darren. 2016. The Mythical Properties of Police Body-Worn Cameras: A Solution in the Search of a Problem. Surveillance \& Society 14 (1): 138-44.

PATF (Police Accountability Task Force). 2016. Recommendations for Reform: Restoring Trust Between the Chicago Police and the Communities They Serve. Chicago: Police Accountability Task Force. https://chicagopatf.org/wpcontent/uploads/2016/04/PATF Final Report 4 13 16-1.pdf [accessed May 15, 2017].

PERF (Police Executive Research Forum). 2017. Citizen Perceptions of Body-Worn Cameras: A Randomized Controlled Trial. Washington, DC: Police Executive Research Forum. https://perf.memberclicks.net/assets/bodyworncameraperceptions.pdf [accessed September 14, 2017].

Piza, Eric L. 2018. The History, Policy Implications, and Knowledge Gaps of the CCTV Literature: Insights for the Development of Body-Worn Video Camera Research. International Criminal Justice Review, April 2, 2018.

PTFCP (President's Task Force on 21st Century Policing). 2015. Final Report of the President's Task Force on 21st Century Policing. Washington, DC: Office of Community Oriented Policing Services. https://www.phillypolice.com/assets/formsreports/TaskForce_FinalReport.pdf [accessed March 20, 2017].

Ramachandran, Vishnu. 2017. False Hope: Body-worn Cameras as Community Policing in Durham, North Carolina. UNC JOURney 1 (1): 7-15. https://uncjourney.unc.edu/files/2017/05/JOURneySpring2017vol1Digital.pdf $\#$ page $=7$ [accessed May 17, 2018].

Ray, Rashawn, Kris Marsh, and Connor Powelson. 2017. Can Cameras Stop the Killings? Racial Differences in Perceptions of the Effectiveness of Body-Worn Cameras in Police Encounters. Sociological Forum 32 (S1): 1,032-050.

Reiner, Robert. 2010. The Politics of the Police. Oxford: Oxford University Press.

Rice, Glen, E. 2014. Amid More Scrutiny of Police, KC-Area Departments Employ Body-Mounted Cameras. Kansas City Star, December 1, 2014. http://www.kansascity.com/news/local/crime/article4230852.html [accessed September 20, 2017 ]. 
Rosenbaum, Dennis P, Amie M. Schuck, Sandra K. Costello, Darnell F. Hawkins, and Marianne K. Ring. 2005. Attitudes Toward the Police: The Effects of Direct and Vicarious Experience. Police Quarterly 8 (3): 343-65.

Ross, Janell, and Wesley Lowery. 2017. Black Lives Matter Shifts from Protests to Policy Under Trump. Chicago Tribune, May 4, 2017. http://www.chicagotribune.com/news/nationworld/ct-black-lives-matter-trump-20170504-story.html [accessed September 14, 2017].

Sanders, Carrie B., and James Sheptycki. 2017. Policing, Crime and 'Big Data'; Towards a Critique of the Moral Economy of Stochastic Governance. Crime, Law and Social Change 68 (1): 1-15.

Sandhu, Ajay. 2017. 'I'm Glad That Was On Camera': A Case Study of Police Officers' Perceptions of Cameras. Policing and Society 29 (2): 223-35.

Sandhu, Ajay, and Kevin D. Haggerty. 2017. High-Visibility Policing: Policing on Camera and the Crisis of Legitimacy. Theoretical Criminology 21 (1): 78-95.

Schneider, Christopher. 2016. Policing and Social Media: Social Control in an Era of New Media. Lanham, MD: Lexington.

Schneider, Christopher. 2018. An Exploratory Study of Public Perceptions of Police Conduct Depicted in Body Worn Camera Footage on YouTube. Annual Review of Interdisciplinary Justice Research 7: 118-48.

Smith, David. 2007. New Challenges to Police Legitimacy. In Transformations of Policing, edited by Alistair Henry and D. J. Smith, 273-306. London: Ashgate.

Snyder, Sara A, Saeed Rahman, Jamie K. Hamilton, Hana T. Hamdi, Columbia Epidemiology of Human Rights Study Group, Anjoli Anand, Anna Andel, Laurene Barlet, Juliana L. Bennington, Cyril Bennouna, Chris B. Boyer, Matthew Cato, Eric Cioe-Pena, Courtney A. Clark, Mary Crippen, Justine Dowden, Jennifer B. Fearon, Lorraine Fei, Angie Hamouie, Ian R. Kurashige, Samina Lutfeali, Kathryn Martin, Ramón Millán, Adrienne Pizatella, Maria C. Quinn, Kate Ross-Hopley, Emily Wilkinson Salamea, Kaitlin Shaw, Mallory C. Sheff, Priyam Thind, Anaise M. Williams, and Les Roberts. 2017. The Eric Garner Case: Statewide Survey of New York Voters' Response to Proposed Police Accountability Legislation. Journal of Social Service Research 43 (1): 1-17.

Sommers, Roseanna. 2015. Will Putting Cameras on Police Reduce Polarization. Yale Law Journal 125 (5): 1,304-362.

Sousa, William H., Terance D. Miethe, and Mari Sakiyama. 2017. Inconsistencies in Public Opinion of Body-Worn Cameras on Police: Transparency, Trust, and Improved Police-Citizen Relationships. Policing: A Journal of Policy and Practice 12 (1): $100-08$.

Spencer, Suzanne. and Delong, Katie. 2019. “Technology is Evolving”: Greenfield PD Implements Body Cameras as Survey Shows Majority Support. Fox6 News, April 1, 2019. https://fox6now.com/2019/04/01/technology-is-evolving-greenfieldpd-implements-body-cameras-as-survey-shows-majority-support/ [accessed July 9, 2019].

Stalcup, Meg, and Charles Hahn. 2016. Cops, Cameras, and the Policing of Ethics. Theoretical Criminology 20 (4): $482-501$.

Stanley, Jay. 2015. Police Body-Mounted Cameras: With Right Policies in Place, a Win for All. New York: American Civil Liberties Union. https://www.aclu.org/other/police-body-mounted-cameras-right-policies-place-win-all [accessed May 5, 2018].

Stratton, Mary, and Peter Clissold. 2015. Body Worn Video: Considering the Evidence (Final Report of the Edmonton Police Service Body Worn Camera Pilot Project). Edmonton, AB: Edmonton Police Service. http://www.bwvsg.com/wpcontent/uploads/2015/06/Edmonton-Police-BWV-Final-Report.pdf [accessed January 17, 2018].

Sunshine, Jason, and Tom R. Tyler. 2003. The Role of Procedural Justice and Legitimacy in Shaping Public Support for Policing. Law \& Society Review 37 (3): 513-48.

Suss, Joel, Alexis Raushel, Adam Armijo, and Brian White. 2018. Design Considerations in the Proliferation of Police BodyWorn Cameras. Ergonomics in Design 26 (3): 17-22.

Tankebe, Justice. 2013. Viewing Things Differently: The Dimensions of Public Perceptions of Police Legitimacy. Criminology 51 (1): 103-35.

Taylor, Emmeline. 2016. Lights, Camera, Redaction... Police Body-Worn Cameras: Autonomy, Discretion and Accountability. Surveillance \& Society 14 (1): 128-32.

Thomas, Ethan. 2016. The Privacy Case for Body Cameras: The Need for a Privacy-Centric Approach to Body Camera Policymaking. Columbia Journal of Law \& Social Problems 50 (2): 191-228.

Timan, Tjerk. 2016. The Body-Worn Camera as a Transitional Technology. Surveillance \& Society 14 (1): $145-49$.

Tyler, Tom R. 2006. Why People Obey the Law. Princeton: Princeton University Press.

Tyler, Tom R. 2016. Police Discretion in the 21st Century Surveillance State. University of Chicago Legal Forum (1/14): 579614.

Tyler, Tom R. 2017. Procedural Justice and Policing: A Rush to Judgment? Annual Review of Law and Social Science 13 (1): 2953.

Tyler, Tom R., and Peter Degoey. 1995. Collective Restraint in Social Dilemmas: Procedural Justice and Social Identification Effects on Support for Authorities. Journal of Personality and Social Psychology 69 (3): 482-97.

Tyler, Tom R., Peter Degoey, and Heather Smith. 1996. Understanding Why the Justice of Group Procedures Matters: A Test of the Psychological Dynamics of the Group-Value Model. Journal of Personality and Social Psychology 70 (5): 913-30.

Tyler, Tom R., and Yuen Huo. 2002. Trust in the Law: Encouraging Public Cooperation with the Police and Courts. New York: Russell Sage Foundation.

Tyler, Tom R., and Heather Smith. 1997. Social Justice and Social Movements. In Volume 2 of Handbook of Social Psychology, edited by D. Gilbert, S. Fiske, and G. Lindzey, 595-629. New York: McGraw-Hill.

Tyler, Tom R., and Cheryl Wakslak. 2004. Profiling and Police Legitimacy: Procedural Justice, Attributions of Motive, and Acceptance of Police Authority. Criminology 42 (2): 253-82. 
USA White House. 2014. Fact Sheet: Strengthening Community Policing. Washington, DC: White House Office of the Press Secretary. https://obamawhitehouse.archives.gov/the-press-office/2014/12/01/fact-sheet-strengthening-community-policing [accessed July 17, 2017].

van Brakel, Rosamunde, and Paul De Hert. 2011. Policing, Surveillance and Law in a Pre-Crime Society: Understanding The Consequences of Technology Based Strategies. Journal of Police Studies 20 (3): 165-92.

Vitale, Alex S. 2017. The End of Policing. London: Verso

Walker, Samuel. 2012. Institutionalizing Police Accountability Reforms: The Problem of Making Police Reforms Endure. Saint Louis University Law Journal 32 (1): 57-93.

White, Michael Douglas. 2014. Police Officer Body-Worn Cameras: Assessing the Evidence. Washington, DC: Office of Community Oriented Policing Services. https://ric-zai-inc.com/Publications/cops-p289-pub.pdf [accessed May 20, 2018].

White, Michael, and James Coldren. 2017. Body-Worn Police Cameras: Separating Fact from Fiction. PM Magazine, February 12, 2017. https://icma.org/articles/pm-magazine/pm-article-body-worn-police-cameras-separating-fact-fiction [accessed May 12, 2018].

White, Michael, Janne Gaub, and Natalie Todak. 2016. Results from Citizen Survey Research of Body-Worn Cameras (memo). Phoenix, AZ: ASU Center for Violence Prevention and Community Safety. https://static.spokanecity.org/documents/police/accountability/bodycamera/citizen-survey-findings-memo-02-02-2016body-worn-cameras.pdf [accessed June 24, 2016].

Williams, Katherine, and Craig Johnstone. 2000. The Politics of the Selective Gaze: Closed Circuit Television and the Policing of Public Space. Crime, Law and Social Change 34 (2): 183-210.

Willits, Dale, and David Makin. 2017. Show Me What Happened: Analyzing Use of Force through Analysis of Body-Worn Camera Footage. Journal of Research in Crime and Delinquency 55 (1): 51-77.

Wolfe, Scott E., and Justin Nix. 2016. The Alleged "Ferguson Effect" and Police Willingness to Engage in Community Partnership. Law and Human Behavior 40 (1): 1-10.

Yokum, David, Anita Ravishankar, and Alexander Coppock. 2017. Evaluating the Effects of Police Body-Worn Cameras: A Randomized Controlled Trial. Working Paper. Washington, DC: Lab@DC. http://bwc.thelab.dc.gov/TheLabDC MPD BWC Working_Paper 10.20.17.pdf [accessed November 18, 2017]. 